Vol. 11 (4): 881-886 (2021)

\title{
REGULATORY FRAMEWORK ANALYSIS FOR THE BROILER BY - PRODUCTS TREATMENT IN UKRAINE AND THE EU
}

\author{
Olga Tertychna $^{1}$, Galyna Ryabukha ${ }^{2 *}$, Valeriy Pinchuk ${ }^{1}$, Olga Kichigina ${ }^{1}$, Inna Horodynska ${ }^{1}$ \\ ${ }^{1 *}$ Institute of Agroecology and Environmental Management NAAS, Metrologichna Str., 12, Kyiv, 03143, Ukraine; \\ ${ }^{2 *}$ Chernihiv Polytechnic National University, Shevchenka Str.,95, Chernihiv, 14035, Ukraine; \\ "Corresponding author Galyna Ryabukha, e-mail address: g.ryabukha@gmail.com;
}

Received July 2021; Accepted August 2021; Published September 2021;

DOI: https://doi.org/10.31407/ijees11.427

\begin{abstract}
The paper considers the features of the regulatory framework for the treatment of broiler production by-products of in Ukraine and the EU. The main legal act in the field of handling by-products of broiler production in Ukraine is the Law of Ukraine "On by-products of animal origin, not intended for human consumption." As regards the EU Member States, there is also a special Regulation - Regulation (EC) № 1069/2009 of the European Parliament and of the Council of 21 October 2009 laying down rules of treatment for animal by-products and derived products not intended for human consumption and repealing Regulation (EC) № 1774/2002 (Regulation on animal by-products). The paper analyzes the relevant regulations and establishes how the three categories of animal by-products relate to each other, considers the treatment of animal by-products of all three categories of animal by-products.
\end{abstract}

Key words: broiler production by-products, Law of Ukraine, EU Directive, by-products categories, by-products treatment, by-products use, by-products utilization. 